\title{
認知症高齢者の「その人らしさ」に基づく施設個室環境の概念化 CONCEPTUALIZING THE ENVIRONMENT OF PRIVATE ROOM BASED ON “PERSONHOOD” OF ELDERLY WITH DEMENTIA IN GROUP CARE UNIT
}

\author{
赤木徹 也*，鯵 坂誠 之** \\ Tetsuya AKAGI and Shigeyuki AJISAKA
}

\begin{abstract}
The purpose of this study is to clarify conceptualizing the environment of private room based on "Personhood" of elderly with dementia in group care unit and relations between it and dwelling consciousness. The results are summarized as follows. The conceptual model of the environment of private room based on personhood of the elderly with dementia is structured by eight aspect including personalization. The elderly with dementia who think one's final residence has strong consciousness for personalization in conceptual model. In the elderly with dementia based on the recognition of the final residence, it is important that it promotes continuity and autonomy while maintaining personalization and secures social relationship and stability. On the other hand, in the elderly with dementia based on the recognition of the temporary residence, the private properties are not suddenly carried, and it is important to change their recognition little by little.
\end{abstract}

Keywords: Personhood, Conceptualization, Elderly with dementia, Living environment, Private room その人らしさ，概念化，認知症高齢者，住環境，個室

\section{1.はじめに}

認知症高齢者の住環境における QOL 向上には、個別ケアの充実や プライバシーの保護、さらには自立性の援助や安全・安心の確保な ど多様な要因が指摘されているが、その中でもとくに重要な項目の ひとつとして、生活の継続性が挙げられている注 ${ }^{11}$ 。その生活の継続 性を成立させるためには、物理的環境のみならず人との関わりを表 寸社会的環境、ケアや施設の運営などを表す運営的環境を複合的に 捉える必要がある。また、生活の継続性は環境への適応能力が低下 している認知症高齢者にとって、急激な環境移行を回避させるのみ に止まらず、残存能力の維持や向上にもつながる重要な役割を担う ものと考えられている。そのため、生活の継続性は認知症高齢者に 対する多くの住環境評価尺度のひとつとして用いられている。そし て、生活の継続性を評価するための下位次元には、家庭的な環境の 必要性が述へらられているつまり、施設環境においてより家庭的な 環境を創造することが、生活の継続性を高める重要な要因のひとつ であるとされているのである。家庭的な環境は認知症高齢者の環境

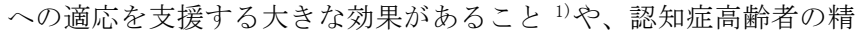
神状態の安定に寄与し、治癒的な効果をもたらす可能性があること 2)などが指摘されている。

認知症高齢者の施設環境整備に目を向けると、そこでは主に共用 空間と個室が挙げられており、共用空間では「家庭らしさ」、個室で は「その人らしさ」に基づく家庭的な環境整備が重要 ${ }^{3)}$, 4) とされて いる。個室環境における「その人らしさ」とは従来、家族の写真な どの個人的な意味を持つ物品によりアイデンティティ（identity） を高めるといったパーソナリゼーション（personalization）という 捉え方がされてきた ${ }^{5)}$ 。

一方、パーソン・センタード・ケアといった理念が提唱されてお り、認知症高齢者のその人らしさを「人として認めること、尊重、 信頼」といった位置付けを中心に据えたパーソンフッド (personhood）という視点で捉える場合もある ${ }^{6)}$ 。パーソンフッド では、その人の内面を反映するために、従来のパーソナリゼーショ ンにおけるアイデンティティのみならず、くつろぎや愛着、社会的 一体性、主体的行動などをも捉えることが重要とされている注2)。 認知症高齢者のその人らしさをパーソンフッドと捉える研究は、 看護や介護の分野において先進的な取組みが散見される ${ }^{7) ~ 9) 。 そ こ ~}$ では、パーソン・センタード・ケアを目指した評価手法を用いてそ の影響を明らかにする取組み ${ }^{7)}$ 、入居者の生活時間を客観的に観

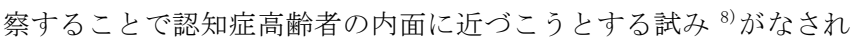
ている。しかしながら、認知症高齢者の個室環境に着目し、「その人 らしさ」を内面から捉えようとする取組みはほとんど行われておら ず、個室環境に関しては家族や施設職員に対してヒアリングを試み るといった間接的な手法が採用されている状況にある ${ }^{10) 。 ~}$

人の認識を直接的に抽出する手法については、発話から意味を捉 え、概念化を図るといった取組み ${ }^{111,12)}$ が行われているものの、それ を認知症高齢者に応用し、認識の違いに応じて施設個室環境の整備 に結び付けるといった研究は未だ十分に行われているとは言い難い。
* 工学院大学建築学部建築デザイン学科 准教授・博士 (工学)

** 大阪府立大学工業高等専門学校総合工学システム学科 講師・博士 (工学)
Assoc. Prof., Dept. of Architectural Design, School of Architecture, Kogakuin Univ., Dr. Eng. Lecturer, Dept. of Technological Systems, Osaka Prefecture University College of Technology, Dr. Eng. 
本研究の目的は、その人らしさをパーソンフッドとして捉え、認 知症高齢者から個室環境の認識に関わる発話を抽出し、その人らし い施設個室環境の概念化を図るとともに、住処としての認識の差異 が概念や設え方に与えうる要因を明らかにすることである。

\section{2. 調査概要}

\section{2-1. 調査対象施設と個室の特徵}

調查対象施設は個人を尊重したケアを志向し、ユニットケアを実 践している特別養護老人ホーム 1 施設（特養）とグループホーム 3 施設（GH1〜GH3）の計 4 施設である。個室の特徵は、(1)個室化され ている事、(2)物の持ち込みが自由な事、(3)ベッドとクローゼットが 備え付けてある 1 施設 (GH3) 以外は基本的にベッドのみが備え付け てあり、その他の物品に関しては入居者に持ち込みを働きかけてい る事である。

\section{2-2. 調査対象となる入居者の選定}

表 1 は調查対象となる入居者の属性と施設概要を示す。調查対象 となる入居者は施設の個室を利用しており、施設長並びに本人と家 族からの了解が得られた認知症高齢者注 3) の内、調查が遂行できた 19 名（男性 3 名、女性 16 名、平均年齢 81.4 歳) である注 4$)$ 。入居者 の選定理由は、(1)調查者との会話が可能である事、(2)内容が大きく 変化することなく首尾一貫した会話が可能であること、(3)移動など の日常生活がある程度自立している事、(4)自身で個室内の設えが可 能である事、である。なお、入居者は基本的に同一地域内、又は近 隣地域から入居しており、入居前・後における立地条件が極端に変 化していないことを確認している。

\section{2-3. 調査手順}

実施期間は 2011 年 10 月から 2012 年 1 月迄である。調查は認知症 高齢者のその人らしさに基づく施設個室環境を明らかにするため、 次の 3 段階の手順で構成される。

\section{(1) 事前調査}

事前調査では、入居者の会話内容をより深く理解するため、施設 の職員から入居者の趣味嗜好、職業 - 生活歴、移動能力、家族構成 などを抽出する。

(2) ヒアリング調査

ヒアリング調查は、入居者から個室環境におけるその人らしさを 導き出すため、各入居者の個室内で自由な発話を促す会話形式によ る聞き取りを実施する。その際、認知症高齢者が個室を自身の環境 としてどのように受け止めているかを明らかにするため、以下の教 示を行う。あなたが暮らしているこの部屋を私に紹介してください。 あなたが部屋で感じている事、あなたの部屋における生活、あなた の部屋に置かれている物など、紹介したい事柄はなんでも結構で す。」その後、発話が途切れた場合にはその度に同じ教示内容を最初 から繰り返し、答えが得られなくなった時点で調査を終了する。な お、入居者との会話をスムーズに行うため、ヒアリング調查に際し て 15 分程度の自己紹介や世間話を踏まえた雑談の時間を設ける。

\section{(3) 物品調查}

物品調査では、入居者の個室内に存在する物理的環境を目視と写 真撮影により調查する。ヒアリング調查により得られた発話の中か ら「物品」に関わる内容を抽出できるよう、個室内における物品の 種類や数、ならびに設置場所などを紙面上に記録する。

表 1 入居者の属性と施設概要

\begin{tabular}{|c|c|c|c|c|c|c|c|c|c|c|c|c|c|c|}
\hline $\begin{array}{l}\text { 入椐 } \\
\text { 者 }\end{array}$ & 性 & \begin{tabular}{|l} 
年 \\
暚
\end{tabular} & $\begin{array}{l}\text { 認 } \\
\text { 知 } \\
\text { 症 } \\
\text { 程 } \\
\text { 度 }\end{array}$ & $\begin{array}{l}\text { 撑 } \\
\text { 告 } \\
\text { 韻 } \\
\text { 度 }\end{array}$ & $\begin{array}{l}\text { 要 } \\
\text { 護 } \\
\text { 度 }\end{array}$ & 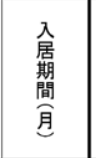 & $\begin{array}{l}\text { 趣 } \\
\text { 味 } \\
\text { 鋅 } \\
\text { 等 }\end{array}$ & 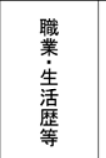 & 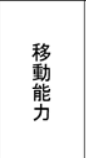 & $\begin{array}{l}\text { 各家 } \\
\text { 族 } \\
\text { 数構 } \\
\text { 成 }\end{array}$ & $\begin{array}{l}\text { 腒 } \\
\text { 售 } \\
\text { 形 }\end{array}$ & $\begin{array}{l}\text { 屠 } \\
\text { 煎 } \\
\text { 腒 } \\
\text { 地 }\end{array}$ & $\begin{array}{l}\text { 施 } \\
\text { 臸 } \\
\text { 態 } \\
\text { 竞 } \\
\text { 地 }\end{array}$ & $\begin{array}{l}\text { 施 } \\
\text { 概 } \\
\text { 要 }\end{array}$ \\
\hline s1 & 男 & 59 & I & J2 & 2 & 1年7ヶ月 & \begin{tabular}{|l|} 
車·塗り絵 \\
文を害く \\
\end{tabular} & - & $\begin{array}{l}\text { 車椅子 } \\
\text { 自立 }\end{array}$ & 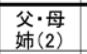 & 老健 & 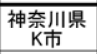 & \multirow{6}{*}{$\begin{array}{c}\text { 特別養護 } \\
\text { 老人特一 } \\
\text { (特養) } \\
\text { 神奈川県 } \\
\text { K市 }\end{array}$} & \multirow{6}{*}{$\begin{array}{l}\text { 入居者数 : } 100 \text { 名（ユニット型個室は } 30 \text { 名） } \\
\text { ユニット数 : } 3 \text { ユニット、ユニット毎の入居者定員 : } 10 \text { 名 } \\
\text { 各ユニットに関わるスタッフ数 : 常勤時間帯 } 2 \sim 3 \text { 名. } \\
\text { 夜間・深夜時間帯 } 2 \text { 名 } / 3 \text { ユニット } \\
\text { 備え付けられている物品 : ベッドのみ } \\
\text { 交換·貸出が可能な物品 : エアコン、カーテン、タンス } \\
\text { 個室面積 : } 14.2 \mathrm{~m}^{2}(\mathrm{~S} 1 \sim \mathrm{S} 6)\end{array}$} \\
\hline S2 & 女 & 61 & I & A1 & 1 & 1年6ヶ月 & \begin{tabular}{|c|} 
踊り·絵描き \\
塗絵·歌 \\
\end{tabular} & 販売員 & 独歩 & 姉 & GH & $\begin{array}{c}\text { 神奈川県 } \\
\text { K市 }\end{array}$ & & \\
\hline S3 & 男 & 89 & III $a$ & A2 & 2 & 1 年 & $\begin{array}{l}\text { カラオケ } \\
\text { カレビ鑑賞 }\end{array}$ & 公務員 & 杖歩行 & \begin{tabular}{|c|} 
妻 \\
息 $(3)$
\end{tabular} & 自宅 & $\begin{array}{c}\text { 神奈川県 } \\
\text { K市 }\end{array}$ & & \\
\hline S4 & 女 & 83 & III $\mathrm{b}$ & A2 & 2 & 1年5ヶ月 & - & 専業主婦 & 独歩 & $\begin{array}{l}\text { 息子 } \\
\text { 娘(2) }\end{array}$ & 自宅 & $\begin{array}{c}\text { 神奈川県 } \\
\text { K市 }\end{array}$ & & \\
\hline S5 & 女 & 89 & II a & B1 & 2 & 1年6ヶ月 & $\begin{array}{c}\text { 体操·写経 } \\
\text { スケート }\end{array}$ & 専業主婦 & 手押し車 & 娘 (2) & 老健 & $\begin{array}{c}\text { 神奈川県 } \\
\text { K市 }\end{array}$ & & \\
\hline S6 & 女 & 87 & III & A1 & 5 & 1 年7ヶ月 & 歌·踊り & 専業主婦 & 独歩 & $\begin{array}{c}\text { 夫 } \\
\text { 息子 }\end{array}$ & 自宅 & $\begin{array}{c}\text { 神奈川県 } \\
\text { K市 }\end{array}$ & & \\
\hline S7 & 男 & 81 & III a & A1 & 3 & 3ヶ月 & 旅行 & 自営業 & 独歩 & $\begin{array}{l}\text { 妻·娘 } \\
\text { 息子 }\end{array}$ & 自宅 & $\begin{array}{c}\text { 東京都 } \\
\text { S区 }\end{array}$ & \multirow{4}{*}{$\begin{array}{l}\text { グループ } \\
\text { ホーム } \\
(\mathrm{GH} 1) \\
\text { 東京都 } \\
\text { S区 }\end{array}$} & \multirow{4}{*}{ 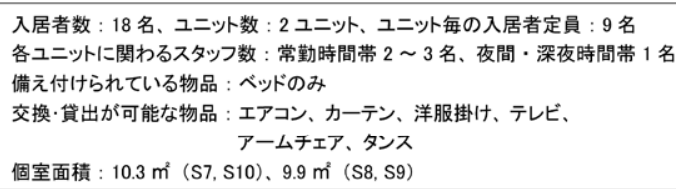 } \\
\hline S8 & 女 & 77 & II $\mathrm{a}$ & A1 & 3 & 5ヶ月 & 手芸 & 専業主婦 & 独歩 & 息子(2) & 自宅 & $\begin{array}{c}\text { 東京都 } \\
\text { S区 }\end{array}$ & & \\
\hline s9 & 女 & 87 & II a & A2 & 3 & 1 年5ヶ月 & テレビ鑑賞 & 専業主婦 & 独歩 & なし & 自宅 & $\begin{array}{c}\text { 東京都 } \\
\text { M区 }\end{array}$ & & \\
\hline S10 & 女 & 86 & II a & A2 & 3 & 1年8ヶ月 & $\begin{array}{l}\text { 百人一首 } \\
\text { 歌·洋服 }\end{array}$ & 専業主婦 & 杖歩行 & 娘 & 自宅 & $\begin{array}{c}\text { 東京都 } \\
\text { S区 }\end{array}$ & & \\
\hline s11 & 女 & 83 & I & J1 & 1 & 3年6ヶ月 & $\begin{array}{c}\text { 服 } \\
\text { 文字を書く }\end{array}$ & $\begin{array}{l}\text { 会社員 } \\
\text { 美容師 }\end{array}$ & 独歩 & $\begin{array}{c}\text { 娘 } \\
\text { 娘の夫 }\end{array}$ & 自宅 & $\begin{array}{c}\text { 神奈川県 } \\
\text { K市 }\end{array}$ & \multirow{6}{*}{$\begin{array}{l}\text { グループ } \\
\text { ホーム } \\
(\mathrm{GH} 2) \\
\text { 神奈川県 } \\
\mathrm{K} \text { 市 }\end{array}$} & \multirow{6}{*}{$\begin{array}{l}\text { 入居者数 : } 18 \text { 名、ユニット数 : } 2 \text { ユニット、ユニット毎の入居者 } \\
\text { 各ユニットに関わるスタッフ数 : 常勤時間帯 } 2 \sim 3 \text { 名、夜間・深 } \\
\text { 備え付けられている物品 : ベッドのみ } \\
\text { 交換·貸出が可能な物品 : エアコン、カーテン } \\
\text { 個室面積 : } 10.1 \mathrm{~m}^{2}(\mathrm{~S} 11, \mathrm{~S} 12, \mathrm{~S} 14, \mathrm{~S} 16) 、 10.4 \mathrm{~m}^{2}(\mathrm{~S} 13, \mathrm{~S} 15)\end{array}$} \\
\hline S12 & 女 & 89 & II b & A2 & 2 & 4年3ヶ月 & 歌を歌う & 専業主婦 & 独歩 & 息子 & 自宅 & $\begin{array}{c}\text { 神奈川県 } \\
\text { K市 }\end{array}$ & & \\
\hline S13 & 女 & 88 & II a & A2 & 1 & 1年5ヶ月 & \begin{tabular}{c|} 
ダンス \\
テレ゙ビ鑑賞
\end{tabular} & 専業主婦 & 独歩 & 弟 & 自宅 & $\begin{array}{c}\text { 神奈川県 } \\
\text { K市 }\end{array}$ & & \\
\hline S14 & 女 & 76 & II a & A1 & 2 & 1年2ヶ月 & \begin{tabular}{|l} 
園芸·写真籃 \\
員・スポーズー
\end{tabular} & 販売員 & 独歩 & 兄の妻 & 自宅 & $\begin{array}{c}\text { 神奈川県 } \\
\text { K市 }\end{array}$ & & \\
\hline S15 & 女 & 88 & III $\mathrm{b}$ & B2 & 4 & 1年2ヶ月 & 写経·詩吟 & 会社員 & $\begin{array}{l}\text { 車椅子 } \\
\text { 自立 }\end{array}$ & 娘 & 自宅 & $\begin{array}{c}\text { 神奈川県 } \\
\text { K市 }\end{array}$ & & \\
\hline S16 & 女 & 88 & I & J1 & 1 & 1ヶ月 & 歌 & 専業主婦 & 独歩 & $\begin{array}{c}\text { 息子(2) } \\
\text { 娘 }\end{array}$ & 自宅 & $\begin{array}{c}\text { 神奈川県 } \\
\text { K市 }\end{array}$ & & \\
\hline S17 & 女 & 71 & III & A1 & 2 & 1年5ヶ月 & 音楽·絵画 & $\begin{array}{l}\text { ピアノ講師 } \\
\text { 専業主婦 }\end{array}$ & 独歩 & 夫·娘 & 自宅 & $\begin{array}{c}\text { 東京都 } \\
\text { B区 }\end{array}$ & \multirow{3}{*}{$\begin{array}{c}\text { グループ } \\
\text { ホーム } \\
\text { (GH3) } \\
\text { 東京都 } \\
\text { B区 }\end{array}$} & \multirow{3}{*}{ 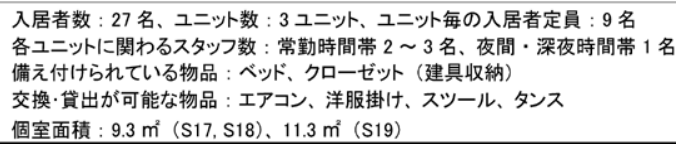 } \\
\hline S18 & 女 & 85 & III & A1 & 2 & 3年 & $\begin{array}{c}\text { 社交ダンス } \\
\text { 旅行 }\end{array}$ & 会社員 & 杖歩行 & 弟 & 自宅 & $\begin{array}{c}\text { 東京都 } \\
\text { B区 }\end{array}$ & & \\
\hline S19 & 女 & 80 & II $\mathrm{b}$ & A1 & 1 & 3年6ヶ月 & - & 専業主婦 & 杖歩行 & 息子 & 自宅 & $\begin{array}{c}\begin{array}{c}\text { 東京都 } \\
\text { B区 }\end{array} \\
\end{array}$ & & \\
\hline
\end{tabular}

注 1) 認知症の程度は「認知症高齢者の日常生活自立度判定基準」を、日常生活自立度は「障害高齢者の日常生活自立度」を用いる。

注 2)「備え付けられている物品」とはベッドやクローゼット（建具収納）のように施設に備え付けられている物品を、「交換・貸出が可能な物品」とは入居者の要望に応じて持込みの 物品との交換や、施設からの貸出が可能な物品を意味する。 


\section{2-4. 分析手法}

表 2 はヒアリング調査より得られた発話数の内訳を、表 3 は発話 内容に基づく分析シートの一例を示す。発話の分析では質的研究に おいて広く採用されている定性的な手法である M-GTA 法（修正版グ ラウンデッド・アプローチ)を応用した分析を用いる ${ }^{13)}$ 。従来の M-GTA 法は、発話より得られた内容を逐語化し、意味を解釈して理 論的飽和化注 5) を迎えるまで「概念」を生成する点に特徴がある。具 体例として示される内容が発話より得られる単位文として抽出され、 複数の入居者が同様の発話をしている場合には、それらの単位文が 分析シートにまとめられる。これら単位文をまとめた内容が定義と して規定され、その定義に基づき生成されるのが概念である。また、 従来の M-GTA 法では概念間の相互関係を「類似」「対極」という 2 つの作用により検討しているが、本研究ではより詳細に相互関係を 見るため、この点を応用し「類似」「対極」「展開」「重複」という4 つの作用に分けて検討を行う。なお、「類似」とは似ている概念の関 係を、「対極」とは対になる概念の関係を、「展開」とは 1 つの概念 から内容が広がる関係を、「重複」とは 2 つ上上の概念を併せ持つ関 係を示す 14), 15)

\section{3. 調査結果と考察}

\section{3-1. その人らしさに基づく施設個室環境の概念モデル}

図 1 は認知症高齢者のその人らしさに基づく施設個室環境の概念 モデルを示す。分析では、発話により得られた概念が理論的飽和化 を迎えるまで生成を行った。その結果、47 概念が生成された。続い

表 2 発話数の内訳

[発話数]

\begin{tabular}{|c|c|c|c|c|c|c|c|c|c|c|}
\hline & S1 & S2 & S3 & S4 & S5 & S6 & S7 & S8 & S9 & S10 \\
\hline 発話数 & 38 & 81 & 55 & 116 & 54 & 10 & 34 & 48 & 61 & 71 \\
\hline 住処の認識 & - & 終 & - & 仮 & - & - & - & - & 仮 & 仮 \\
\hline & S11 & S12 & S13 & S14 & S15 & S16 & S17 & S18 & S19 & 計 \\
\hline 発話数 & 23 & 4 & 22 & 30 & 149 & 27 & 25 & 79 & 103 & 1030 \\
\hline 住処の認識 & - & - & - & - & 終 & - & 仮 & 終 & 終 & - \\
\hline
\end{tabular}

<凡例 > 終 :「終の住処」の認識、仮 :「仮の住処」の認識

$$
\text { 表 } 3 \text { 発話分析シートの一例 }
$$

[入居者:S4, S5, S10, S15, S17]

\begin{tabular}{|c|c|}
\hline 概念 & （2)個人的な活動をしやすい居場所 \\
\hline 定義 & $\begin{array}{l}\text { テレビや趣味作業などの個人的な活動がしやすい居場所を } \\
\text { 自身で選択できると }\end{array}$ \\
\hline 具体例 & 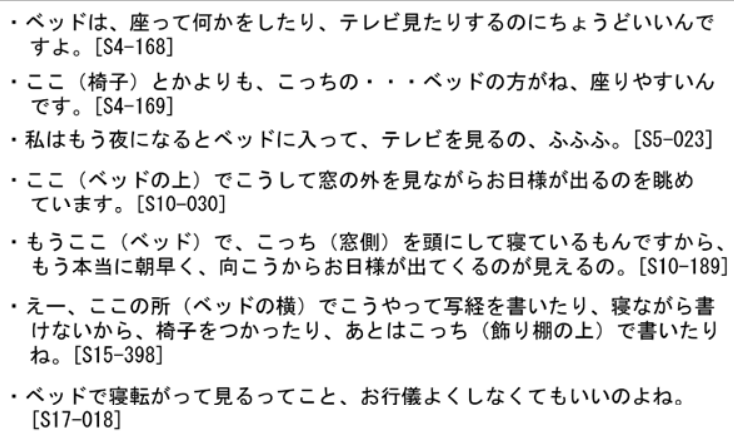 \\
\hline $\begin{array}{l}\text { 理論的 } \\
x \succeq\end{array}$ & 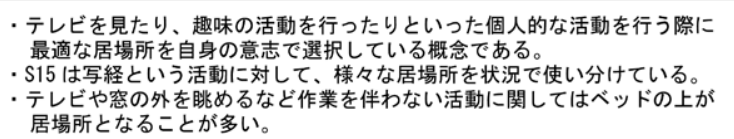 \\
\hline
\end{tabular}

注)具体例の文末に示される[ ]は入居者ごとの発話の通し番号を示す。
て概念間の相互関係を捉えている。この手続きにより、各概念はそ の上位概念であるカテゴリに収束され、さらに上位概念であるコア カテゴリへと収束される。その結果、47 概念は 21 カテゴリに収束 され、さらに 8 コアカテゴリ【I．個人的なこだわり】【II. 生活の継 続性】【III. 人や物との繋がり】【IV. 職員による生活支援】【V.自律 しうる日常生活】【VI. 住空間としての快適性】【VII. 安定した個の居 場所】【VIII. 個室外の空間との連続性】に収束される概念モデルとし て示された注6)。このうち【I】〜【III】は従来のパーソナリゼーシ ヨンといった視点から、【I】〜【VII】は本研究で位置付けているそ の人らしさ、寸なわちパーソンフッドといった視点から捉えられて いる。8コアカテゴリの詳細と相互関係は以下のように整理される。

【I.個人的なこだわり】：自身にとって意味のあるお気に入りの 居場所、趣味嗜好に合わせた個人的な活動、自身の成果を表寸物や お気に入りの物など、個室環境における個人的なこだわりに関する 概念である。これは居心地の良い場所を得ている場合やお気に入り の物に愛着を感じたり、趣味や作業を通じた自己表現の際に得られ る個人的な満足感などがこだわりを生み出しているものと考えられ る。具体的には、座り心地の良いベッドの上をお気に入りの場所と しており椅子やソファには座らない事や、趣味で毎日描いている絵 をその成果として個室内の壁に展示している事などが挙げられる。

【II. 生活の継続性】 : 入居前の生活から行っていた趣味や仕事、 家族や知人といった日常における人との関わり、それらを直接的又 は物を通して間接的に感じられる事など、個室環境において今まで 慣れ親しんだ生活との継続性に関寸る概念である。この概念は入居 前の生活や家族に関わる過去の記憶に基づく発話で構成されること が多いため、認知症高齢者にとって過去の出来事や人との繋がりが、 アイデンティティの維持にも寄与しているものと考えられる。とく に自宅生活から継続的に使用している家具や入居前からの趣味活動 を表す物などが含まれる [II-1］は、【 I 】と【II】に重複する関係 にあることからもその様子が伺える。具体的には、かつて仕事をし ていた当時を思い起こさせるジャケットを洋服掛けに飾っている事 や、亡くなった家族との思い出の写真のみならず入居前に飼ってい たペットに類似した置物を設えている事などが挙げられる。

【III. 人や物との繋がり】: 施設に入居してからの他の入居者や職 員との関わり、入居前からの継続的かつ直接的な家族や知人との交 流、もしくは物を介した間接的な繋がりなど、個室環境を広義に捉 えた場合の社会的な人や物との繋がりに関する概念である。これは 認知症高齢者が他者と繋がりがあることによる安心感や、他者に対 するいたわりの気持ち、他者からの働きかけに対する感謝の気持ち が関係しているものと考えられる。5 つのカテゴリから構成されて おり、[III-2] は訪問者が家族や知人であるか否かにより [ II -2] [III -1）と重複の関係になりうるが、個室に訪問してきた家族や他の入 居者との直接的な交流活動が生じていることを示している。また

【I】は個室環境において「個人的」なこだわりが意識されている のに対して、【III】は第三者との関わりを含む「社会的」な意識が働 いていることから対極の関係にあると捉えられる。具体的には、早 朝テレビを観る際に他の入居者を思いやり音量を下げている事や、 訪問してきた家族と個室で会話などの交流をしている事、さらに少 数ではあるが他の入居者を個室に招いている事などが挙げられる。

【IV. 職員による生活支援】：職員との良好な関係や、安全・体調 
管理などの支援、家具や飾り付けといった職員からの働きかけによ る物的な支援など、個室環境における職員との関わりを通じた支援 に関する概念である。これは認知症高齢者にとって支援がある事に より得られる安心感や住み心地の良さ、支援への感謝の気持ちなど が関係しているものと考えられる。3 つのカテゴリから構成されて おり、[IV-1]は【III】との重複の関係にあり、職員との良好な繋が りが生活支援にも寄与しているものと考えられる。具体的には、夜 中に起きて個室を出ようとすると見守っている職員がすぐに来てく れる事や、入居者の要望に応じて貸し出されたタンスやテレビがあ る事で不自由なく生活ができる事などが挙げられる。

【V. 自律しうる日常生活】：日課などの時間に基づく生活管理が できている事や、体調や安全から見た健康面に関する自己管理、衣 服や小物の収納といった物に関する自己管理ができる事など、個室 環境における自律しうる日常生活に関する概念である。これは自身 の意志が尊重された日常生活の自律が促されているかといった事や
自尊心などが関係しているものと考えられる。3 つのカテゴリから 構成されており、具体的には、安全のため仏壇の線香に自身ではあ えて火を灯さないようにしている事や、自律した生活を行うため普 段着る洋服はすぐ手に取れるようベッドに掛けているといった整理 の仕方を工夫している事などが挙げられる。

【VI. 住空間としての快適性】：空間の明るさや清潔感などに基づ く快適性や、それを維持するための設備・備品による調整、静かさ や心地良さを踏まえた空間の落ち着きなど、個室環境における住ま いとしての快適性に関する概念である。これは認知症高齢者が個室 で暮らす上で心地よいと感じる空間であることや、個室自体が清潔 に保たれているといった清潔感なども関係しているものと考えられ る。3 つのカテゴリから構成されており、具体的には、ベランダの 存在により朝夕の採光が調整され心地よさを感じる事や、清潔感を 維持するためタンスの上にのみ物を置いている事などが挙げられる。

【VII. 安定した個の居場所】：個室がリビングなどの共用空間とは

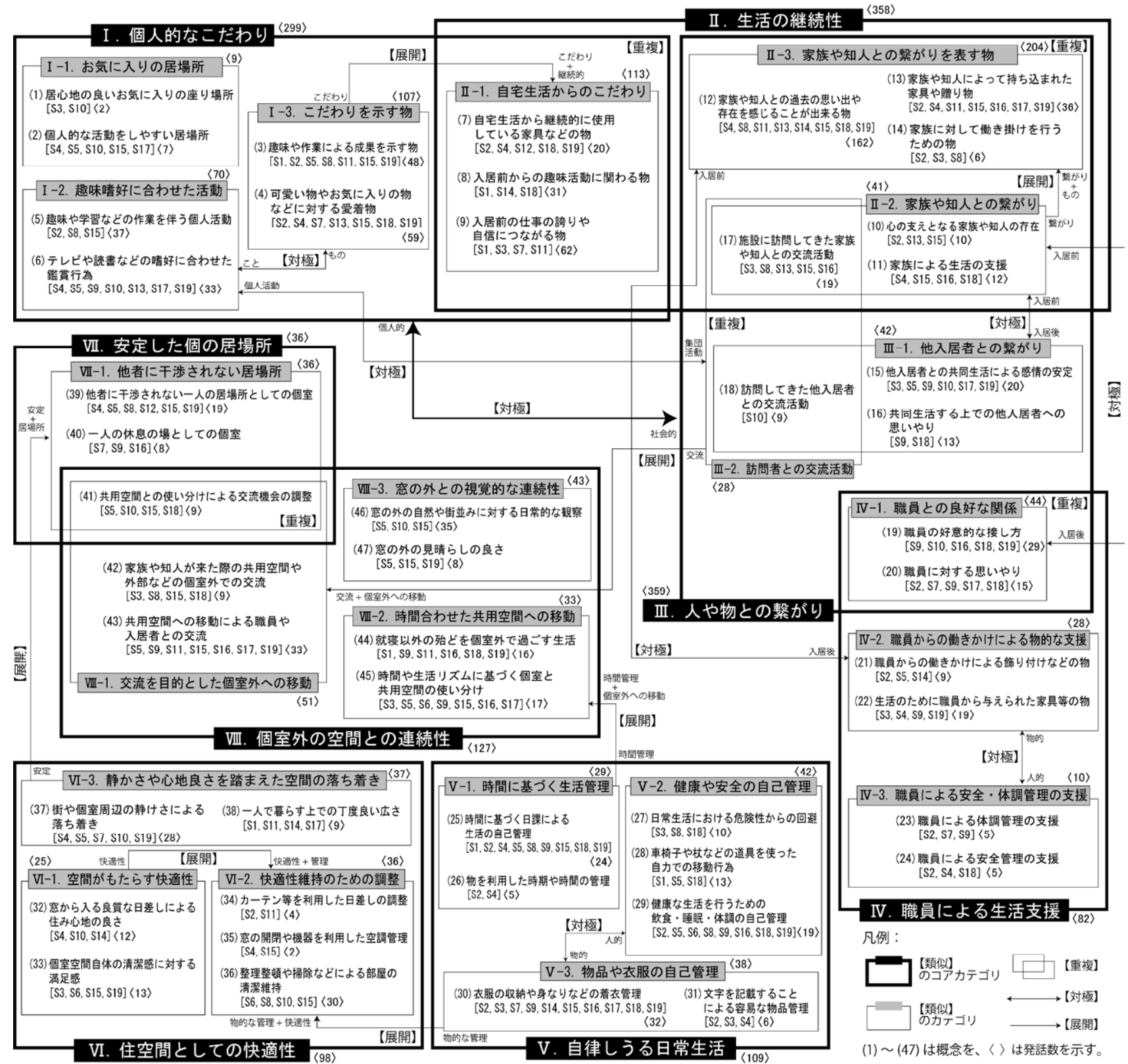

図 1 認知症高齢者のその人らしさに基づく施設個室環境の概念モデル 
＜終の住処と認識している入居者の概念モデル＞
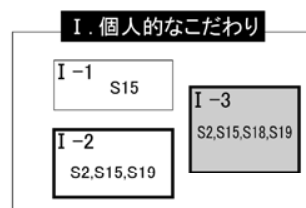

VI. 安定した個の居場所

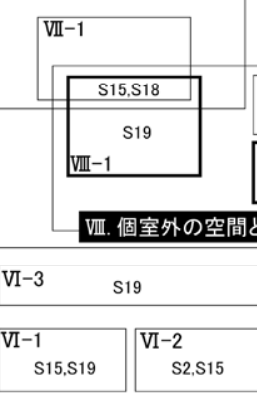

VI. 住空間としての快適性
II. 生活の継続性

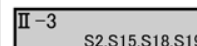

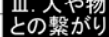

L

S15,S18,S19

との連続性

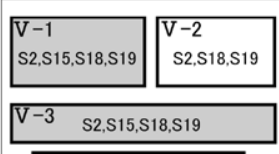

V. 自律した日常生活
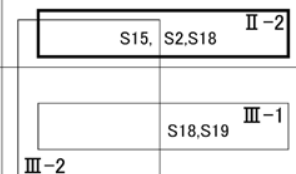

IV-1

IV-2

$\mathrm{S} 2 \mathrm{~S} 19$

＜仮の住処と認識している入居者の概念モデル＞

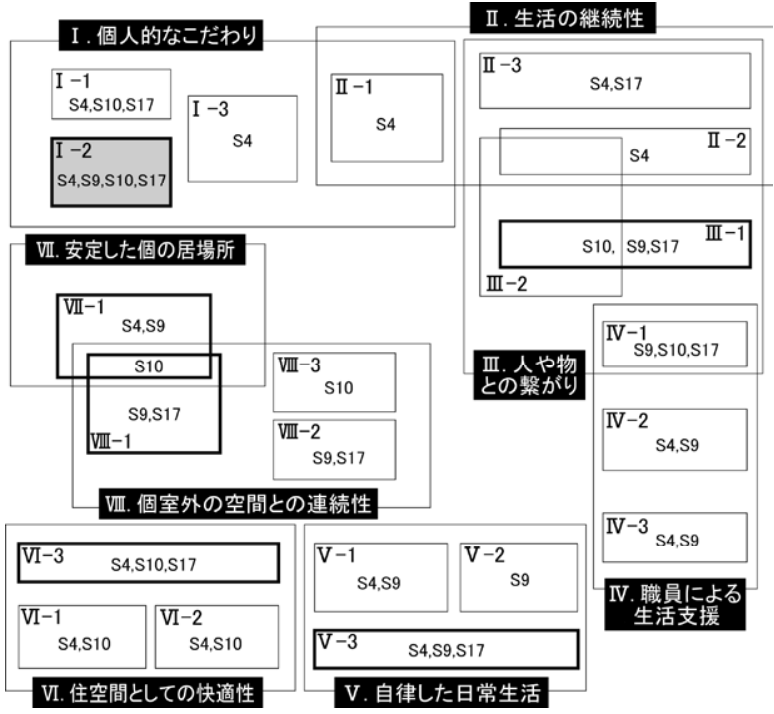

＜凡例 >太枠+網掛け: 4 名ともに捉えられているカテゴリ 太枠のみ:3 名に捉えられているカテゴリ

図 2 住処としての認識の差異と概念モデルとの関係性

異なり他者に干渉されない一人の居場所として確保されている事や、 休息するための居場所となっている事など、個室環境が自身だけの 安定した居場所として確保されている事に関する概念である。これ は認知症高齢者が集団生活の中で落ち着きや安心感を得るための場 所として個室環境を捉えているものと考えられる。1 つのカテゴリ から構成されており、その一部は交流の機会を調整するため個室と 共用空間との使い分けを行うといった意味から [VIII-1］と重複の関 係にある。具体的には、共用空間を他者との交流空間と捉え、個室 を一人になれる空間として捉えるなどの使い分けが挙げられる。

【VIII. 個室外の空間との連続性】 : 空から見える風景との視覚的な 連続性や、他の入居者や家族との交流を目的とした個室外への移動、 時間や生活リズムに合わせた共用空間での活動など、個室内のみな らず個室外一興味や活動が広がる事に関する概念である。これは認 知症高齢者が空外の風景を見ることで得られる心地良さや個室外と の繋がりを感じる事、主体的な活動や社会生活の広がりを感じる事 などが関係しているものと考えられる。3 つのカテゴリから構成さ れており、具体的には、日常的に様々な他の入居者と会話をし情報 を得るために共用空間に行くようにしている事や、太陽が昇るのを 毎朝空から眺めるようにしている事などが挙げられる。

\section{3-2. 住処としての認識の差異と概念モデルとの関係性}

住処としての認識の差異が概念モデルとどのような関係にあるか を明らかにするため、入居者が自由に発話している内容から、「ここ でね、私は一生暮らすんですよ。(S2)」のように自身の個室環境を 【終の住処】として認識している入居者のグループ（以下、終住 G】） と、「もうちょっとこちらでお世話になって、まあいつかは家に帰ろ うと思ってますのよ。（S9）」のように【仮の住処】として認識して いる入居者のグループ（以下、【仮住 $\mathrm{G} 】$ ) に大別した。その結果、 19 名の入居者のうち、S2・S15・S18・S19 の 4 名が【終住 G】、S4・ $\mathrm{S} 9 \cdot \mathrm{S} 10 \cdot \mathrm{S} 17$ の 4 名が【仮住 $\mathrm{G}$ 】大別されたため、その認識の差 異に着目し、概念モデルとの関係を検討する。なお、残りの入居者 による発話からは住処としての認識を判断出来なかったため分析対 象から除いている。
図 2 は住処としての認識の差異と概念モデルとの関係性を示す。 【終住G】において4名ともに捉えられているカテゴリは、［Ｉ－3]［II $-3][\mathrm{V}-1][\mathrm{V}-3]$ であり、個人的なこだわりを示寸物や、家族や知人 との繋がりを表す物、物品や衣服の自己管理のように、主に「物品」 に焦点が当てられている。なお、 4 名のうち 3 名に捉えられている カテゴリは、コアカテゴリ【VI】を除いて概㸚どのコアカテゴリに も分散している。

一方、【仮住 G】において 4 名ともに捉えられているカテゴリは、 [ I -2]のみであり、個人的な趣味嗜好に合わせた活動が捉えられて おり、「物品」に対しては比較的焦点が当てられていない。また、4 名のうち 3 名に捉えられているカテゴリについては偏りが見られ、 [ I -1] [VII-1] [VI-3]のようにお気に入りの居場所や他者に干渉され ない居場所、静かさや心地よさを踏まえた空間の落ち着きなどのよ うに「居場所」に焦点が当てられている。また、 [ III-1] [IV-1] [VIII-1] のように他の入居者や職員とのつながりを求める場合には共用空間 への移動を伴うなどの「活動」にも焦点が当てられている。「物品」 については $[\mathrm{V}-3]$ のように自己管理に関わる物品や衣服について捉 えているといった特徵が見られる。

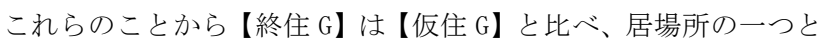
なりうる個室に対して、より個人的なこだわりを「物品」を通じて 個室環境に反映させつつ、特に家族や知人との繋がりを表す物など を設えることで生活の継続性の意識を高めているものと考えられる。

【仮住 G】は、いずれ自宅に帰ることを意識しているため、個室 環境に対する個人的なこだわりや家族との繋がりを踏まえた生活の 継続性に関寸る意識は低いものと考えられる。但し、他の入居者を 思いやりテレビの音量を下げている事、個室に招くこともあるなど 他の入居者との繋がりは配慮している点に注意する必要がある。従 って、【終住 G】において焦点が当てられている [ I -3]や [ II -3]のよ うに、従来のパーソナリゼーション ${ }^{16)}$ においてもアイデンティティ を維持していくための重要な内容として捉えられている物品を通じ た個人的なこだわりのみならず、他の入居者や職員との繋がりや趣 味嗜好に合わせた活動にも着目寸ることが重要である。 


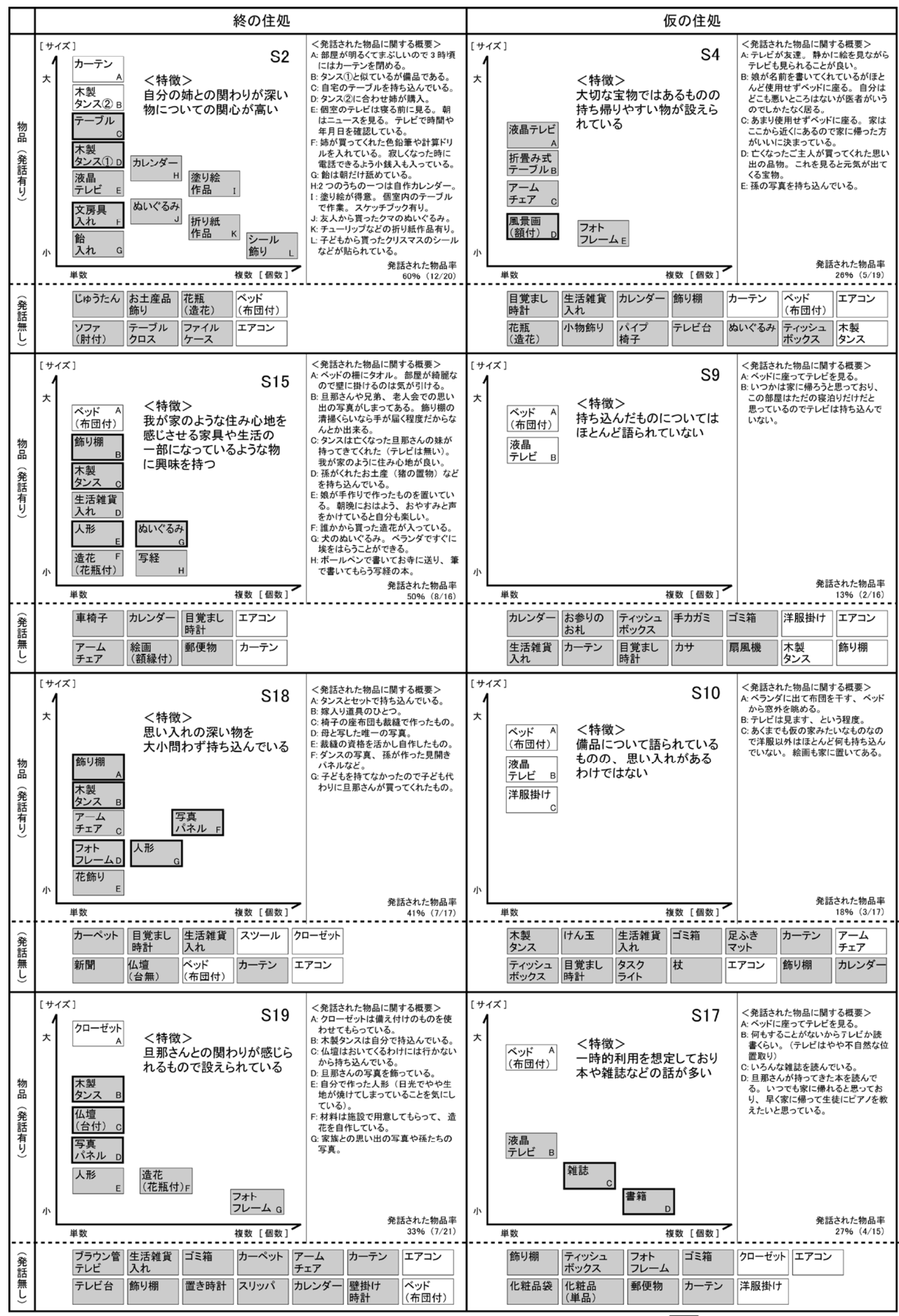

<凡例 $>\square$ 持込みの物品 $\square$ 持込みの物品以外（備え付けられている物品 又は 交換・貸出が可能な物品） $\square$ 発話に見られる特徵 発話された物品率=「個室内の物品」に占める「発話された物品」の割合

図 3 住処としての認識の差異と発話された物品との関係性 
そして、これらを踏まえて、交流を目的とした個室外一の移動や生 活の継続、自律といった捉え方に広げていくことが、個室環境の領 域性を高めていくことへ繋がるものと考えられる注7)。

\section{3-3. 住処としての認識の差異と個室環境の設え方}

図 3 は住処としての認識の差異と発話された物品との関係性を示 す。ヒアリング調查により得られた発話の中から「物品」に関わる 内容を抽出し、住処としての認識の差異に応じて個室環境の設え方 を検討する。そこで個室内の物品に占める発話された物品の割合を 「発話された物品率」として見た場合、【終住 $\mathrm{G} 】$ のうが【仮住 $\mathrm{G} 】$ よりも高いことが明らかとなった。サイズや個数に着目すると、単 数ではあるものの木製タンスや飾り棚、仏壇といった比較的大きな 物に焦点が当てられているがわかる。また複数のものはサイズが小 さく、折り紙や塗り絵、造花などの自身で作成した作品などが挙げ られている。また、【終住 G】のほうが【仮住 G】よりも個室環境に 後から持込まれている物品に焦点が当てられており、【仮住 $\mathrm{G}$ 】で取 り上げられている場合には風景画や雑誌、書籍といった簡易に持ち 帰ることの出来る物品が挙げられている点に特徵が見られる。

さらに、【終住 G】において持ち込まれている物品は、兄弟姉妹や 配偶者との関わりが深い思い出の写真や、自宅のような住み心地を 感じさせる思い入れのあるタンスなどが挙げられている。【仮住 $\mathrm{G}$ 】 では備品について焦点が当てられているものの、愛着やなじみのあ る物品として説明されるのではなく、他の物を説明する際に発話の 中で補足的に用いられている。その場合、家に帰ることを前提とし た内容や、何もすることがないのでしかたなく行動している内容な どを説明する発話の中で用いられることが多く、個室環境を入居者 自身の個の居場所として認識していない様子が伺える。

従って、【終住 G】のような場合には、折り紙や塗り絵などの自身 で作成した作品などを展示しつつ、物品や衣類の自己管理が可能な 木製タンスや飾り棚といった家具などを持込むことにより、自宅の ような安定した居場所としての認識を高め、自律しうる日常生活を 促すことが重要である。【仮住 $\mathrm{G} 】$ のよな場合には、現状において 施設に入所することが一時的な利用として想定されているため、急 激になじみの家具や愛着のある物を持ち込むのではなく、趣味嗜好 に合わせた活動を支援しつつ、個室環境を安定した個の居場所とし て認識させ、他の入居者や職員との良好な関係づくりを支援してい くことが重要である。

\section{4. まとめ}

1) パーソンフッドの視点から捉えられる認知症高齢者のその人らし い施設個室環境の概念は【I . 個人的なこだわり】【II. 生活の継 続性】【III. 人や物との繋がり】【IV. 職員による生活支援】【V. 自 律しうる日常生活】【VI. 住空間としての快適性】【VII. 安定した個 の居場所】【VIII. 個室外の空間との連続性】により構成される。

2) その人らしい施設個室環境の概念や設え方に与えうる要因は、住 処としての認識の差異に応じて、以下のように示される。

(1)とくに【I . 個人的なこだわり】【II. 生活の継続性】【III. 人や 物との繋がり】といった概念は、従来のパーソナリゼーション の意味を内包していることから、終の住処として認識している 認知症高齢者にとっては、これを維持しつつ【VIII. 個室外の空 間との連続性】や【V. 自律しうる日常生活】といった捉え方
へと広げていくことが、個室環境の領域性を高めていく要因と なりうる。

(2)仮の住処として認識している認知症高齢者にとっても、パーソ ナリゼーションに関する整備は重要であるが、そのためになじ みの家具や愛着のある物などを急激に持ち込むことは、彼らに 自宅一帰ることが出来ないといった不安を与える要因になり かねない。そのため、アイデンティティを維持しやすい家族の 写真や、持ち帰りが容易な物などの設えにより、徐々に領域性 を高めていくことが、緩やかに終の住処としての認識を強化さ せていく上で重要である。

\section{謝辞}

本研究を遂行するにあたり、ご協力いただきました入所者の皆様 に改めてお礼申し上げます。また、調查対象とさせていただきまし た施設の施設長をはじめスタッフの方々には、格別のご配慮を賜り ました。ここに、謹んで感謝の意を表します。

注

注 1)文献 1 では、物理的環境がもたらす治療効果の可能性や認知症の人々とその 介護者のための、より支援的な環境と質の高い生活の創造の必要性が述べら れており、すべての治癒環境は家庭が本来もつ属性を、できるかぎり可能な範 囲で“しっかりともちつづける(hold on)”ドきであること、すなわち生活の継続性 が重要であることが示唆されている。

注 2)文献 6 より、パーソン・センタード•ケアの理念の提唱者であるキットウッドは、パ ーソンフッドを核としてそれを維持し、認知症の人々の生活の質を高めていくク アの在り方を示唆している。

注 3)認知症の程度は『認知症高齢者の日常生活自立度判定基準」の活用につい て』(平成 18 年 4 月 3 日老健第 135 号厚生省老人保健福祉局長通知の別添) による。以下に基準の内訳を示す。I : 何らかの認知症を有するが日常生活は 家庭内及び社会的にはほぼ自立している。II : 日常生活に支障を来すような症 状・行動や意思疎通の困難さが多少見られても誰かが注意していれば自立でき る。II a : 家庭外で前述 II の状態が見られる。II b : 家庭内でも前述 II の状態が 見られる。III : 日常生活に支障を来寸ような症状・行動や意思疎通の困難さがと きどき見られ介護を必要とする。IIII: 日中を中心として前述亚の状態が見られる。 IIIb: 夜間を中心として前述IIIの状態が見られる。IV : 日常生活に支障を来すよ うな症状・行動や意思疎通の困難さが頻繁に見られ常に介護を必要とする。 M： 著しい精神症状や問題行為あるいは重篤な身体疾患が見られ専門医療を必要 とする。また、日常生活自立度は「障害高齢者の日常生活自立度」(平成 3 年 11 月 18 日老健第 $102-2$ 号 厚生省大臣官房老人保健福祉部長通知) によ る。以下に基準の内訳を示す。 $\mathrm{J}$ :何らかの障害等を有するが日常生活はほぼ 自立しており独力で外出する。 $\mathrm{J} 1$ : 交通機関等を利用して外出する。 $\mathrm{J} 2$ : 隣近所 へなら外出する。 A: 屋内での生活は概数自立しているが介助なしには外出しな い。A $\mathrm{A}$ :介助により外出し日中はほとんどベッドから離れて生活する。 $\mathrm{A} 2$ : 外出 の頻度が少なく日中も寝たり起きたりの生活をしている。B:屋内での生活は何ら かの介助を要し日中もベッド上での生活が主体であるが座位を保つ。B1: 車椅 子に移乗し食事・排泄はベッドから離れて行う。B2:介助により車椅子に移乗す る。C: 1 日中ベッド上で過ごし排泄・食事・着替において介助を要する。 C 1 : 自 カで寝返りをうつ。C2:自力では寝返りもうたない。

注 4)ヒアリング調查は 21 名に対して行ったが、その内の 2 名は調查開始以後に不 穏な状況が生じてしまいヒアリングを継続出来なかったことから、調查を途中で 中止している。従って、その 2 名を調查対象から除外し、調査を完遂できた 19 名より得られた発話デー夕を基に分析を行う。

注 5)文献 13 より、理論的飽和化とは、データから新たに重要な概念が生成されなく なり、新たにデータを収集して確認すべき問題点がなくなったことを意味すると されている。

注 6)47 概念はヒアリング調査により得られた 1030 個の発話数により生成され、最終 的に構成される 8 コアカテゴリは重複を含むため 1468 個の発話数により構成さ れている。 
注 7)文献 16 上り、特養の入居者は、与えられた個室に入居後ただちに物を持込み 一気に自己の空間として領域化するのではなく、生活の中で少しずつ物を持ち 込むことで環境に働きかけながら時間を掛けて領域化していく傾向が示されて おり、本研究の調查結果と概齐の傾向が一致していることを確認している。

\section{参考文献}

1) ユリエル・コーヘン, ジェラルド・D・ワイズマン, 岡田威海(監訳), 浜田裕子(訳): 老人性痴呆症のための環境デザイン, 症状緩和と介護をたすける生活空間づ くりの指針と手法, 彰国社, 1995

2) Judd S, Marshall M, Phippen P. Design for Dementia. London: Hawker Publications; 1998.

3）赤木徹也:家庭らしさを感じさせる居住環境のしつらい,一建築学・住居学の観 点からみた「家庭的」一, 特集「家庭らしさ」とはなにか, 老年社会科学, 第 30 巻, 第 4 号, pp.509-515, 2009.1

4) 辻泰代, 渡辺裕美:その人らしさを継続するための認知症高齢者グループホー ム入居支援, 入居前アセスメントと入居時ケアに焦点をあてて, 介護福祉学, 第 18 巻, 第 1 号, pp.48-56, 2011.4

5) Sloane PD, Mitchell CM, Weisman G, et al. : The Therapeutic Environment Screening Survey for Nursing Home (TESS-NH); An Observational Instrument for Assessing the Physical Environment of Institutional settings for Persons With Dementia, The Journals of Gerontology Series B: Psychological Sciences and Social Sciences 57, pp.69-78, 2002

6）トム・キットウッド, 高橋誠一(訳): 認知症のパーソン・センタード•ケア, 新しいケ アの文化へ, 筒井書房, 2005

7）鈴木みずえ, 水野裕, 坂本凉子他:パーソン・センタード・ケアを目指した認知症
ケアマッピング(DCM)の発展的評価介入の有效性, スタッフと認知症高齢者に 及ぼ寸効果, 日本認知症攵学会誌, 第 10 巻, 第 3 号, pp.356-368, 2011.10

8）木野美恵子: 生活時間を軸にした認知症介護の一考察, 介護福祉学, 第 16 巻, 第 2 号, pp.229-237, 2009.10

9）小木曽加奈子:認知症高齢者の“よくない状態(ill-being)”の指標に基づいた分 析, 生活全体に配慮が必要な認知症高齢者に着目をして, 介護福祉学, 第 18 巻, 第 2 号, pp.155-161, 2011.10

10)林悦子・小滝一正・林玉子: 個室空間の住まい方特性, 一特別養護老人ホーム の個の空間に関する研究一, 日本建築学会計画系論文集, 第 517 号, pp.131-138, 1999.3

11)嶌末憲子・小嶋章吾: 高齢者ホームヘルプ実践における生活場面面接の研究 一M-GTA を用いた利用者の「持てる力を高める」プロセスの検討一, 介護福祉 学, 第 12 巻, 第 1 号, pp.105-117, 2005.10

12）堀恭子: 認知症デイサービスの職員は介護をどのように意識しているか一介護 職員の体験を探索的にモデル化する試み一, 老年社会科学, 第 32 巻, 第 3 号, pp.317-327, 2010.10

13)木下康仁:グラウンデッド・セオリー・アプローチの実践, 弘文堂, 2003

14)赤木徹也・鯵饭誠之: 認知言語学的アプローチに基づく都市空間の概念化に 関する基礎的研究, 日本建築学会計画系論文集, No.679, pp2043-2052, 2012.9

15)赤木徹也・小林将夫・鯵坂誠之: 日常の家庭生活に内在寸る表象的幸福感に 関する概念モデルとその視覚的イメージの関係性, 人間・環境学会誌 MERA Journal, Vol.15, No.1, pp1-10, 2012.7

16)橘弘志, 外山義, 高橋鷹志他: 個室型特別養護老人ホームにおける個室内の 個人的領域形成に関寸る研究, 日本建築学会計画系論文集, No. 500 , pp.133-138, 1997.10 